of Captain Cook who related many of these incidents to the writer, ${ }^{2}$ the North Brothers, Doc Carver, Buffalo Bill, General Dodge, and many other characters of the old west, John Nelson had the ability and reputation of being one of the best of the bull whackers, Indian fighters, hunters and squaw men. His unmarked grave is somewhere out along Medicine Creek. No one now living recalls its location, but the above may help to preserve the memory of his life and exploits.

2 John H. Cook, who was an active participant in the taming of the old west and knew many of its outstanding figures, died at his well-known Agate Springs Ranch in Sioux County, Nebraska in 1944.

\title{
More Criminal Cases in Iowa Courts
}

Except for the years of World War II, the courts in the respective counties of Iowa have had to deal with an increasing number of criminal cases each year over the past quarter-century, according to a recent study prepared by Walter A. Lunden of Iowa State University. The 6,151 cases heard in 1958 represents a rise of approximately 44.3 per cent over those of 1935 , and may be compared to a 10 per cent growth in population during this period.

\section{Banking Department Superintendents}

G. A. Messenger July 4, 1917-January 30, 1920 M. V. Henderson, Jr.__ January 31, 1920-June 30, 1921 W. J. Murray__July 1, 1921-May 3, 1923 Robert L. Leach May 4, 1923-June 30, 1925 (Deceased) L. A. Andrews July 1, 1925-June 30, 1929 July 1, 1929-June 30, 1933 (Deceased) D. W. Bates July 1, 1933-June 30, 1941 (Deceased) M. W. Ellis___July 1, 1941-March 16, 1946 (Deceased) N. P. Black April 9, 1946-June 30, 1957 Lee Chandler July 1, 1957-October 14, 1957 (Deceased) Joe H. Gronstal December 1, 1957-Present 
Copyright of Annals of Iowa is the property of State of Iowa, by \& through the State Historical Society of Iowa and its content may not be copied or emailed to multiple sites or posted to a listserv without the copyright holder's express written permission. However, users may print, download, or email articles for individual use. 